\title{
Antibody-Dependent Cellular Cytotoxicity
}

National Cancer Institute

\section{Source}

National Cancer Institute. Antibody-Dependent Cellular Cytotoxicity. NCI Thesaurus.

Code C16298.

The target killing of a cell depending on antibody recognition. An antibody is directed to the target by antigen-binding arms and anchors to the killer cell by an Fc receptor. The identity of the target cell varies, but it must possess surface IgG whose Fc portion is intact. The effector "killer" cell possesses Fc receptors. It may be a lymphocyte lacking conventional B- or T-cell markers, or a monocyte, macrophage, or polynuclear leukocyte, depending on the identity of the target cell. The reaction is complement-independent. 